\title{
Adoption of Hazard Adjustments by Large and Small Organizations: Who is Doing the Talking and Who is Doing the Walking?
}

Abdul-Akeem Sadiq, Indiana University-Purdue University Indianapolis

Sadiq, Abdul-Akeem (2011) "Adoption of Hazard Adjustments by Large and Small Organizations: Who is Doing the Talking and Who is Doing the Walking?," Risk, Hazards \& Crisis in Public Policy: Vol. 2: Iss. 3, Article 6.

Available at: http://www.psocommons.org/rhcpp/vol2/iss3/art6

DOI: $10.2202 / 1944-4079.1067$ 


\title{
Adoption of Hazard Adjustments by Large and Small Organizations: Who is Doing the Talking and Who is Doing the Walking?
}

\author{
Abdul-Akeem Sadiq, Indiana University-Purdue University Indianapolis
}

\begin{abstract}
Environmental hazards pose a considerable and genuine threat to the survival of organizations. However, organizations can increase their likelihood of survival by adopting various hazard adjustments. Prior studies on hazard adjustments have found a positive relationship between the adoption of hazard adjustments and organization size. However, no study on hazard adjustments has grouped hazard adjustments into active and passive and studied the relationship between active and passive hazard adjustments and organization size. The author investigates whether large organizations adopt more active and passive hazard adjustments than small organizations, using data from a survey of 227 organizations in Memphis, Tennessee. The results show that large organizations adopt more active and passive hazard adjustments than small organizations and both large and small organizations engage in different types of hazard adjustments.
\end{abstract}

KEYWORDS: emergency management, active and passive hazard adjustments, organizations, Memphis

Author Notes: Abdul-Akeem Sadiq, Assistant Professor, School of Public and Environmental Affairs, Indiana University Purdue University Indianapolis; email: asadiq@iupui.edu. I thank the National Science Foundation for providing the fund and appreciate the opportunity given by the MAE Center to carry out this study. My appreciation goes to my research collaborators-Drs. Chris Weible, Rob Olshansky, Arleen Hill, Jeremy Bateman, and Divya Chandrasekhar-for their research assistance and support. I also thank Drs. Simon Andrew, Chris Weible, and Erin Fordyce for their advice and candid reviews of the manuscript. Finally, I thank two anonymous reviewers for their constructive comments. I am solely responsible for the opinions, findings, and conclusion contained in this study. 
Sadiq: Active and Passive Hazard Adjustments

\section{Introduction}

Environmental hazards are ubiquitous. When environmental hazards come in contact with organizations, they can pose a tremendous threat to the survival of organizations (Alesch et al. 2001) by causing, for example, employee death, destruction of properties, and disruption of services. The substantial damage to businesses in Los Angeles caused by the Northridge earthquake in 1994 (Tierney 1997) and the over 18,000 businesses destroyed by Hurricane Katrina in 2005 (Stephens 2007) are vivid reminders of the potential destructive nature of environmental hazards. The good news is that organizations can reduce the impact of environmental hazards by adopting hazard adjustments.

This study distinguishes between active hazard adjustments and passive hazard adjustments and assumes that active hazard adjustments are more capable of reducing organizations' impact from environmental hazards than passive hazard adjustments. Here, active hazard adjustments are proactive measures taken by organizations to reduce the impact of environmental hazards while passive hazard adjustments are measures that involve an organization simply discussing actions to be taken. Active hazard adjustments include activities such as securing computers and strengthening parts of a building. Examples of passive hazard adjustments include mentioning a potential disaster in an organizational meeting or discussing short-term responses to disasters. Organizations that adopt active hazard adjustments may stand a better chance of surviving disasters in comparison to those that only enact passive hazard adjustments.

Disaster researchers have extensively studied hazard adjustments at the household and community levels. Unfortunately, little research has been done to understand hazard adjustments at the organizational level. In addition, no study on hazard adjustments has grouped hazard adjustments into active and passive and studied the relationship between active and passive hazard adjustments and organization size. This study attempts to bridge this gap in the hazard adjustments literature.

The data for this study come from a survey administered to a sample of 227 organizations in Memphis/Shelby County, Tennessee in the fall of 2006. Memphis is an interesting case study due to its propinquity to the New Madrid Seismic Zone (NMSZ) and its status as the most populated city in Tennessee. The relevant literature is presented first, then the study area and methods. These sections are followed by the results, discussion and conclusions sections. The paper ends with suggestions for future research endeavors. 


\section{Literature Review}

In this study, environmental hazards refer to events that have the potential to cause harm or loss to individuals, organizations, community, or the natural environment. When environmental hazards like hurricanes, terrorism, and tornadoes come in contact with organizations, the survival of organizations may be threatened (Alesch et al. 2001). Organizations cannot control the physical characteristics of environmental hazards, such as intensity and frequency (Nigg 1996); they can, however, reduce potential disaster impacts by adopting hazard adjustments. Hazard adjustments are “... actions that intentionally or unintentionally reduce risk from extreme events in the natural environment" (Lindell and Perry 2000, 461- 462). The importance of hazard adjustments in any community cannot be overemphasized because hazard adjustments can help to enhance community resilience to disasters and emergencies. "[Community] resilience is ... a set of capacities that can be fostered through interventions and policies, which in turn, help build and enhance a community's ability to respond and recover from disasters" (Cutter et al. 2010, 2).

Hazard adjustments may be grouped according to the four phases of emergency management - mitigation, preparedness, response, and recovery (Prater and Lindell 2000). Hazard adjustments primarily associated with the first two phases are pre-impact and consist of hazard mitigation activities (e.g., land use planning), emergency preparedness (e.g., training first responders), and insurance purchase (Prater and Lindell 2000). In this study, hazard adjustments refer to pre-impact hazard adjustments in the mitigation and preparedness phases that intentionally help organizations reduce the impact of environmental hazards.

The field of disaster research has expanded since its inception in the early 1950s (Quarantelli 2003). In particular, the area of hazard adjustments has exhibited significant growth. However, the strengths of this literature have been either at the household level (e.g., Arlikatti 2009; Atwood and Major 2000; Burton et al. 1978; Davis 1989; Dooley et al. 1992; Edwards 1993; Farley 1998; Jackson 1981; Lindell and Perry 2000; Lindell and Prater 2002; Lindell and Whitney 2000) or community level (e.g., Berke and Beatley 1992; Burby et al. 2000; Drabek et al. 1983; May and Birkland 1994; Mushkatel and Nigg 1987; Prater and Lindell 2000; Wood 2004). At the household level, researchers have studied the relationship between hazard adjustments and independent variables like risk perception (e.g., Ge, Peacock and Lindell 2011; Jackson 1977; 1981), hazard salience (e.g., Turner 1983; Turner et al. 1986), earthquake experience (e.g., Dooley et al. 1992; Turner et al. 1986), culture (e.g., Palm and Carroll 1998), and gender, age, educational level, income, ethnicity, and marital status 
(e.g., Lindell, Arlikatti and Prater 2009). ${ }^{1}$ Similarly, at the community level, researchers have examined the relationship between hazard adjustments and independent variables like community resources (e.g., May and Birkland 1994), politics (e.g., Prater and Lindell 2000), and local policy entrepreneurs (e.g., Wood 2004).

Unfortunately, disaster researchers have largely neglected the study of disasters at the organizational level (Tierney 1997; Webb et al. 2000). The exceptions include the excellent pioneering work of some notable researchers (e.g., Dahlhamer and D'Souza 1997; Drabek 1991; 1994a; 1994b; Nigg and Tierney 1994; Quarantelli et al. 1979; Webb et al. 2000). More recent studies at the organizational level include Sadiq (2009; 2010) and Sadiq and Weible (2010). Regardless of the aforementioned studies, there is a need for more research. The goal of this study is to contribute to the hazard adjustment literature at the organizational level.

Previous disaster studies have found a significant relationship between hazard adjustments and the size of organizations (e.g., Dahlhamer and D'Souza 1997; Drabek 1991; 1994a; 1994b; Quarantelli et al. 1979; Sadiq 2010). In fact, firm size is the most consistent (Dahlhamer and D'Souza 1997) and important (Webb et al. 2000) predictor of hazard adjustments at the organizational level in studies conducted by the Disaster Research Center at the University of Delaware. For example, in a study of 18 chemical companies, Quarantelli et al. (1979) found that larger companies engaged in more planning than smaller companies. Similarly, in a study of disaster evacuation planning in the tourist industry, Drabek $(1991 ; 1994 a ; 1994 b)$ found that larger firms had more extensive disaster evacuation plans than firms with fewer employees. Furthermore, Sadiq (2010) found a positive relationship between the number of mitigation and preparedness measures adopted and organization size.

From the preceding discussion, it is clear that some work has been done to understand the relationship between hazard adjustments and organization size. However, no study has attempted to break down hazard adjustments into active and passive hazard adjustments and explore how active and passive hazard adjustments relate to organization size. Knowing the relationship between organization size and active and passive hazard adjustments would help to ascertain whether small and large organizations are adopting proactive (active) hazard adjustments that can reduce the impact of environmental hazards, or are just talking about disaster issues (passive hazard adjustment), which may not help organizations reduce the impact of environmental hazards as effectively. The findings in this study may help to better understand why some organizations survive disasters and others do not.

\footnotetext{
${ }^{1}$ See Lindell and Perry (2000), for an extensive review of the household hazard adjustments literature.
} 
The research question presented is "Do large organizations adopt more active and passive hazard adjustments than small organizations?" The author also investigates the sub-question "What types of hazard adjustments do large and small organizations most frequently engage in?" The first question sheds light on whether large organizations not only talk about disasters, but also engage in proactive activities that are capable of reducing the impact of environmental hazards. The purpose of the second question is to ascertain whether large and small organizations engage in similar or different types of hazard adjustments.

\section{Study Area: Memphis/Shelby County, Tennessee}

About 650,000 people live in Memphis (United States Census Bureau 2010), making it the largest city in Tennessee. Earthquakes are a big disaster risk in the Memphis area due to the hazard posed by the NMSZ. In fact, three powerful earthquakes occurred in this region between December 16, 1811 and February 7, 1812 (United States Geological Survey (USGS) 2008). Furthermore, USGS (1998) estimated that there is more than a 90 percent probability of a moderate earthquake (magnitude 6-7) hitting the NMSZ within the next 50 years. Although earthquakes may pose a large disaster risk, the Memphis area also faces threats from other potential hazards like floods, tornadoes, ice storms, chemical spills, fires, severe storms, and violent crimes.

Focusing on organizations in Memphis/Shelby County is necessary for three reasons. First, the rarity of major disasters in Memphis/Shelby County in recent time poses challenges for organizations who wish to adopt hazard adjustments. The absence of major disasters can make organizations apathetic and reluctant to adopt hazard adjustments (Lindell and Perry 2007; May 1986). Second, a vast majority of studies on earthquakes focus on the west coast, especially California (e.g., Celsi et al. 2005; Jackson and Mukerjee 1974; May and Wood 2003; Mulilis and Duval 1995). Very few studies have analyzed responses to earthquake hazard in Memphis (e.g., Edwards 1993) and only a few have examined the NMSZ where seismic hazards have low probabilities and high consequences (e.g., Atwood and Major 2000; Farley 1998; Major 1998; Mushkatel and Nigg 1987; Olshansky 1994). Therefore, this study adds to the somewhat limited literature on the NMSZ. Third, studies on organizational preparedness (e.g., Dahlhamer and D’Souza 1997; Webb et al. 2000) suggest that organizations in Memphis/Shelby County do little to prepare for disasters. 
Sadiq: Active and Passive Hazard Adjustments

\section{Methods}

\section{Data Collection}

The data used in this study was collected for a larger project that examined the influence of organizational structures on earthquake decision-making in Memphis/Shelby County, Tennessee. The research team, which consisted of three professors and three graduate students, collected disaster related information from a sample of public, private, and non-profit organizations. The target organizations included, but were not limited to, utility companies, schools, health facilities, chemical companies, financial institutions, religious institutions, and restaurants. The data gathering occurred in two phases consisting of interviews and surveys.

In the spring and summer of 2006, the research team conducted 15 exploratory interviews with 15 different organizations in Memphis/Shelby County. The interviews, which consisted of open-ended questions, were conducted in person or via telephone with representatives of these organizations. Interview questions addressed attitudes toward hazard management and risk information, as well as organizational actions to reduce risks. The interviews, which took approximately 30-60 minutes, were summarized and sent back to the interviewees to verify the accuracy of the information provided.

During the fall of 2006, the research team administered a survey. The earlier interviews helped to better frame the survey questions, which were in two parts. The first part consisted of questions regarding risk issues in organizations and what actions organizations were taking to address them. The second part contained questions requesting demographic information from the representatives of organizations answering the surveys.

With the help of the Memphis Regional Chambers of Commerce, the research team queried an online reference service, ReferenceUSA, using "number of employees" as a key index variable to allow organizations of all sizes in the Memphis Metropolitan Area to be surveyed and represented in sufficient numbers. Initially, the research team used 11 employee size categories, which ranged from no employee to 9999 employees. The research team re-categorized "number of employees" into seven categories by merging some categories with few observations together. From the seven categories, the research team randomly selected 100 organizations from each of the first six categories, selected the entire population of 101 organizations from the last category, and then added 32 utility companies for a total of 733 organizations.

The research team mailed a letter on the University of Memphis letterhead to each of the 733 organizations. This letter described the study and sought participation from the 733 organizations. The research team then mailed the first batch of surveys and followed-up with postcards, and then the second batch of 
surveys. The research team merged information on organizational characteristics recorded in ReferenceUSA, such as name, address, number of employees, and zip code with information from the survey to generate the organizational survey dataset. Out of the 733 organizations, 227 organizations returned the survey, giving an overall response rate of about 31 percent. Table 1 shows the seven organization size categories used, and the codes, frequencies and percent of the total sample for each category.

Table 1. Sample Make-up by Size Category

\begin{tabular}{|l|c|c|c|}
\hline $\begin{array}{l}\text { Number of } \\
\text { Employees }\end{array}$ & Code & Frequency & $\%$ \\
\hline $1-9$ & 1 & 37 & 17.21 \\
\hline $10-19$ & 2 & 22 & 10.23 \\
\hline $20-49$ & 3 & 30 & 13.95 \\
\hline $50-99$ & 4 & 32 & 14.88 \\
\hline $100-249$ & 5 & 47 & 21.86 \\
\hline $250-499$ & 6 & 33 & 15.35 \\
\hline$>=500$ & 7 & 14 & 6.51 \\
\hline Total & & $\mathbf{2 1 5}$ & $\mathbf{1 0 0}$ \\
\hline
\end{tabular}

The dataset is unique in two ways. First, it contains rare information on organization representatives' perspective on how their organizations address disaster risks. Gathering disaster related information on organizations is difficult because some organizations are afraid of the potential consequences of divulging such information (Auf der Heide 1989). Second, it contains information on organization hazard adjustments for different types of hazards in an area subject to seismic risk. There is a tendency for researchers investigating disaster preparedness in organizations to focus on specific hazards (Mileti 1999). This dataset contains valuable information that can help to understand what Memphis/Shelby County organizations are doing to prepare for not only earthquakes, but also a host of other hazards like tornadoes, ice storms, floods, and hurricanes.

\section{Variable Definition and Analysis}

In this study, tests for difference in means were used to answer the research questions. As discussed in a previous section, past studies suggest a positive relationship between hazard adjustments and organization size. The author operationalizes the independent variable, organization size, by the number of 
employees in an organization and develops two size categorizes: small organizations ( $\leq 19$ employees) and large organizations ( $>19$ employees). The author uses the same categorization as Dahlhamer and D'Souza (1997); their study also surveyed organizations in Memphis/Shelby County, Tennessee on disaster related issues.

The dependent variables are active hazard adjustments and passive hazard adjustments. Active hazard adjustments consist of seven mitigation and preparedness activities, while passive hazard adjustments consist of three mitigation and preparedness activities (see Table 2 for the activities that fall under active and passive hazard adjustments). Active hazard adjustments are proactive measures taken by organizations to reduce the impact of environmental hazards. For example, strengthening parts of their buildings may help reduce building damage if an earthquake occurs. Passive hazard adjustments considered include organizations mentioning potential disasters that could affect them, discussing short-term responses to disasters, or discussing long-term strategies for disaster recovery. At first glance, one might not consider these three activities as hazard adjustments. However, this study assumes that meetings and discussions in organizations about disasters are precursors to the adoption of active hazard adjustments. In short, by holding meetings and having discussions about disasters, organizations can identify the hazards facing them, implement strategies to address the hazards, and allocate resources to carry out specific active hazard adjustments that have been agreed upon. For example, when organizations mention potential disasters in their meetings, what they are doing is similar to the first step of risk assessment - hazard identification - which is crucial to reducing organizations' susceptibility to hazards (Schwab, Eschelbach and Brower 2007).

The ten hazard adjustments were measured by the survey question, "Has your organization engaged in any of these activities over the past year?" Each of the activities has two options, yes and no. The author created ten dummy variables and assigned a 1 to organizations that engaged in a particular activity and 0 to organizations that did not engage in a particular activity. The responses for each respondent were added to arrive at the number of active (Cronbach's alpha $=0.81)$ and passive $($ Cronbach's alpha $=0.83)$ hazard adjustments for each observation.

This study examined these ten mitigation and preparedness activities because they have been identified in the literature (e.g., Dahlhamer and D'Souza 1997; Webb et al. 2000). Nevertheless, the author recognizes that there are other possible mitigation and preparedness activities organizations can adopt (e.g., whether organizations have stockpiles of food and water). 


\section{Results}

Table 2 shows the number and percentage of organizations, both small and large, that adopted the ten hazard adjustments. Table 3 presents the descriptive statistics for the dependent variables. About 73 percent of the organizations in the sample are classified as large based on the criteria outlined above.

Table 2. Active and Passive Hazard Adjustments and their Frequencies by Organization Size

\begin{tabular}{|c|c|c|c|c|}
\hline \multirow{2}{*}{ Hazard Adjustments } & \multicolumn{2}{|c|}{$\begin{array}{c}\text { Small } \\
\text { Organizations }(\mathrm{N}=59)\end{array}$} & \multicolumn{2}{|c|}{$\begin{array}{l}\text { Large Organizations } \\
\qquad(\mathrm{N}=156)\end{array}$} \\
\hline & $\begin{array}{l}\text { Number } \\
\text { Adopting }\end{array}$ & $\begin{array}{c}\% \\
\text { Adopting }\end{array}$ & $\begin{array}{l}\text { Number } \\
\text { Adopting }\end{array}$ & $\begin{array}{c}\% \\
\text { Adopting }\end{array}$ \\
\hline \multicolumn{5}{|l|}{ Active Hazard Adjustments } \\
\hline $\begin{array}{l}\text { Attended disaster meetings/training } \\
\text { courses outside your organization }\end{array}$ & 11 & 18.6 & 86 & 55.1 \\
\hline $\begin{array}{l}\text { Held disaster-related } \\
\text { workshops/training within your } \\
\text { organization }\end{array}$ & 7 & 11.9 & 86 & 55.1 \\
\hline $\begin{array}{l}\text { Arranged site visits by consultants or } \\
\text { experts to better prepare for disasters }\end{array}$ & 5 & 8.5 & 52 & 33.3 \\
\hline $\begin{array}{l}\text { Provided information to } \\
\text { customers/members of the community } \\
\text { on issues related to disasters }\end{array}$ & 11 & 18.6 & 52 & 33.3 \\
\hline $\begin{array}{l}\text { Assessed or evaluated vulnerability to } \\
\text { disasters or estimated potential losses } \\
\text { from disasters }\end{array}$ & 20 & 33.9 & 93 & 59.6 \\
\hline $\begin{array}{l}\text { Engaged in non-structural mitigation } \\
\text { measures (e.g., securing computers) }\end{array}$ & 20 & 33.9 & 96 & 61.5 \\
\hline $\begin{array}{l}\text { Engaged in structural mitigation } \\
\text { measures (e.g., strengthening parts of } \\
\text { a building) }\end{array}$ & 6 & 10.2 & 43 & 27.6 \\
\hline \multicolumn{5}{|l|}{ Passive Hazard Adjustments } \\
\hline $\begin{array}{l}\text { Mentioned a potential disaster in an } \\
\text { organizational meeting }\end{array}$ & 26 & 44.1 & 116 & 74.4 \\
\hline $\begin{array}{l}\text { Discussed short-term responses to } \\
\text { disasters in an organizational meeting }\end{array}$ & 21 & 35.6 & 113 & 72.4 \\
\hline $\begin{array}{l}\text { Discussed long-term strategies for } \\
\text { recovery from disasters in an } \\
\text { organizational meeting }\end{array}$ & 10 & 16.9 & 79 & 50.6 \\
\hline
\end{tabular}


Sadiq: Active and Passive Hazard Adjustments

Table 3. Descriptive Statistics for Dependent Variables

\begin{tabular}{|l|c|c|c|c|c|}
\hline Variable Description & \multicolumn{1}{c}{ N } & Mean & \multicolumn{1}{c|}{ Std. Dev. } & Min & Max \\
\hline $\begin{array}{l}\text { Number of active hazard } \\
\text { adjustments }\end{array}$ & 208 & 2.97 & 2.29 & 0 & 7 \\
\hline $\begin{array}{l}\text { Number of passive hazard } \\
\text { adjustments }\end{array}$ & 214 & 1.78 & 1.24 & 0 & 3 \\
\hline
\end{tabular}

From Table 2, it is apparent that large organizations adopt more of both active and passive hazard adjustments than small organizations. Further examination reveals that both small and large organizations most frequently engage in mentioning a potential disaster in organizational meetings. In addition, small organizations least frequently engage in arranging site visits with consultants or experts to better prepare for disasters, while large organizations least frequently engage in adopting structural mitigation measures.

This study uses difference of means tests to answer the question "Do large organizations adopt more active and passive hazard adjustments than small organizations?" The difference of means test is an appropriate technique to use because it can be used to ascertain if there is a statistical difference between small and large organizations with respect to the active and passive hazard adjustments they adopt. Table 4 presents the results of the difference of means tests for both active and passive hazard adjustments. With respect to active hazard adjustments, large and small organizations adopt averages of 3.36 and 1.39 (out of seven) respectively. The absolute difference in averages is 1.97 and is statistically significant $(\mathrm{p}<0.001)$. With regards to passive hazard adjustments, large organizations adopt an average of 2.03 (out of three), while the average for small organizations is one (out of three). The absolute difference in averages is 1.03 and is statistically significant $(\mathrm{p}<0.001)$.

In an additional analysis, difference of means tests were carried out for each of the ten hazard adjustments. In each case, the mean hazard adjustment for large organizations is greater than the mean hazard adjustment for small organizations (see Table 5). The differences are statistically significant $(\mathrm{p}<0.1)$ for all the hazard adjustments.

Table 4. Difference of Means Tests for Active and Passive Hazard Adjustments

\begin{tabular}{|l|c|c|c|c|c|}
\hline Variable & \multicolumn{1}{c}{ df } & \multicolumn{1}{c}{$\begin{array}{c}\text { Large Org } \\
\text { Mean }\end{array}$} & $\begin{array}{c}\text { Small Org } \\
\text { Mean }\end{array}$ & Difference & t-value \\
\hline $\begin{array}{l}\text { Active Hazard } \\
\text { Adjustments }\end{array}$ & 197 & 3.36 & 1.39 & -1.97 & $5.79 * * *$ \\
\hline $\begin{array}{l}\text { Passive Hazard } \\
\text { Adjustments }\end{array}$ & 203 & 2.03 & 1.00 & -1.03 & $5.63 * * *$ \\
\hline$* * * p<0.001$
\end{tabular}


Risk, Hazards \& Crisis in Public Policy, Vol. 2 [2011], Iss. 3, Art. 6

Table 5. Difference of Means Tests for Each of the Ten Hazard Adjustments

\begin{tabular}{|c|c|c|c|c|c|}
\hline Variable & df & $\begin{array}{l}\text { Large Org } \\
\text { Mean }\end{array}$ & $\begin{array}{c}\text { Small Org } \\
\text { Mean }\end{array}$ & Difference & t-value \\
\hline \multicolumn{6}{|c|}{ Active Hazard Adjustments } \\
\hline $\begin{array}{l}\text { Attended disaster } \\
\text { meetings/training } \\
\text { courses outside your } \\
\text { organization }\end{array}$ & 206 & 0.56 & 0.20 & -0.36 & $4.85^{* * *}$ \\
\hline $\begin{array}{l}\text { Assessed or evaluated } \\
\text { vulnerability to } \\
\text { disasters or estimated } \\
\text { potential losses from } \\
\text { disasters }\end{array}$ & 203 & 0.62 & 0.37 & -0.25 & $3.17 * *$ \\
\hline $\begin{array}{l}\text { Held disaster related } \\
\text { workshops/training } \\
\text { within your } \\
\text { organization }\end{array}$ & 206 & 0.57 & 0.13 & -0.44 & $6.12 * * *$ \\
\hline $\begin{array}{l}\text { Provided information to } \\
\text { customers/members of } \\
\text { the community on } \\
\text { issues related to } \\
\text { disasters }\end{array}$ & 205 & 0.34 & 0.20 & -0.14 & $1.88^{*}$ \\
\hline $\begin{array}{l}\text { Arranged site visits by } \\
\text { consultants or experts } \\
\text { to better prepare for } \\
\text { disasters }\end{array}$ & 206 & 0.34 & .09 & -0.25 & $3.65 * * *$ \\
\hline $\begin{array}{l}\text { Engaged in non- } \\
\text { structural mitigation } \\
\text { measures (e.g., securing } \\
\text { computers) }\end{array}$ & 205 & 0.64 & 0.36 & -0.28 & $3.69 * * *$ \\
\hline $\begin{array}{l}\text { Engaged in structural } \\
\text { mitigation measures } \\
\text { (e.g., strengthening } \\
\text { parts of a building) }\end{array}$ & 207 & 0.28 & 0.11 & -0.17 & $2.66 * *$ \\
\hline \multicolumn{6}{|c|}{ Passive Hazard Adjustments } \\
\hline $\begin{array}{l}\text { Mentioned a potential } \\
\text { disaster in an } \\
\text { organizational meeting }\end{array}$ & 204 & 0.77 & 0.46 & -0.31 & $4.44 * * *$ \\
\hline $\begin{array}{l}\text { Discussed in an } \\
\text { organizational meeting } \\
\text { short-term responses to } \\
\text { disasters }\end{array}$ & 207 & 0.74 & 0.38 & -0.36 & $5.13 * * *$ \\
\hline $\begin{array}{l}\text { Discussed in an } \\
\text { organizational meeting } \\
\text { long-term strategies for } \\
\text { recovery from disasters }\end{array}$ & 206 & 0.52 & 0.18 & -0.34 & $4.48 * * *$ \\
\hline
\end{tabular}


Finally, the author conducted a sensitivity analysis to ascertain if recategorizing organization size would lead to a different result. This analysis used new categories; small organizations were categorized as those with 99 employees or fewer and large organizations as those with more than 99 employees. The proportions of small and large organizations were 56.3 percent and 43.7 percent, respectively. This re-categorization notwithstanding, the results are consistent with those based on the original organization size categories (see Table 6).

Table 6. Results of Sensitivity Analysis

\begin{tabular}{|l|c|c|c|c|c|}
\hline Variable & df & $\begin{array}{c}\text { Large Org } \\
\text { Mean }\end{array}$ & $\begin{array}{c}\text { Small Org } \\
\text { Mean }\end{array}$ & Difference & t-value \\
\hline $\begin{array}{l}\text { Active Hazard } \\
\text { Adjustments }\end{array}$ & 197 & 3.92 & 1.98 & -1.94 & $6.64 * * *$ \\
\hline $\begin{array}{l}\text { Passive Hazard } \\
\text { Adjustments }\end{array}$ & 203 & 2.32 & 1.29 & -1.02 & $6.42 * * *$ \\
\hline$* * *$ p $<0.001$
\end{tabular}

\section{Discussion}

Previous studies on the relationship between the adoption of hazard adjustments and organization size did not distinguish between hazard adjustments that are proactive (active) and those that are not (passive). For example, Sadiq (2010) gives equal weight to ten hazard adjustments. Giving equal weight to ten different hazard adjustments may create a wrong perception of organizational preparedness. For instance, a small organization that engages in one active hazard adjustment (e.g., engages in structural mitigation) may be perceived as being less prepared compared to a large organization that engages in two passive hazard adjustments (e.g., mentions a potential disaster in an organizational meeting and discusses short-term responses). As a matter of fact, the smaller organization should be more prepared due to the proactive nature of the activity it adopts.

This study is an attempt to distinguish between hazard adjustments that are proactive and those that are not and to understand how this distinction relates to organization size. The research question being investigated is, "Do large organizations adopt more active and passive hazard adjustments than small organizations?" The expectation based on prior studies is that large organizations would adopt more passive and active hazard adjustments than small organizations. This study finds that large organizations do, indeed, adopt more active and passive hazard adjustments than small organizations. This finding is in line with those of Dahlhamer and D'Souza (1997), Drabek (1991; 1994a; 1994b), Quarantelli et al. (1979), and Sadiq (2010). This finding is an indication that large organizations not only hold meetings to identify potential hazards and develop 
strategies to respond and recover from the identified hazards, but they also adopt proactive measures that can help them reduce the damages that might result from the identified hazards.

One possible explanation for why large organizations adopt more of both active and passive hazard adjustments than smaller organizations is that larger organizations have more resources to devote to hazard reduction. This resource argument is common in the disaster literature at the household (Mileti 1999), community (May and Birkland 1994; Wood 2004) and organizational levels (Dahlhamer and D'Souza 1997; Mileti et al. 1993).

This study also investigates the question "What types of hazard adjustments do large and small organizations most frequently engage in?" Using descriptive statistics, this study finds that both small and large organizations most frequently engage in mentioning a potential disaster in an organizational meeting. This result is not surprising because this passive hazard adjustment requires little effort compared to active hazard adjustments. In addition, small organizations least frequently engage in arranging site visits with consultants or experts to better prepare for disasters, while large organizations least frequently engage in adopting structural mitigation measures. Again, these findings are not surprising due to the level of effort required for the two activities. Nevertheless, one implication of these findings is that lack of resources to adopt hazard adjustments can be a constraint not only to small organizations, but to large organizations as well, depending on the hazard adjustment under consideration.

\section{Conclusion}

In sum, both small and large organizations are doing the talking and walking, but large organizations are doing more talking and walking than small organizations. By doing more walking (i.e., adopting active hazard adjustments), larger organizations may stand a better chance of surviving disasters than their smaller counterparts.

An important limitation is that the data used in this study are based on the expressed actions of organization representatives and there is no way of knowing the actual hazard adjustments Memphis/Shelby County organizations adopted prior to the survey. If expressed actions regarding hazard adjustments are substantially different from the actual hazard adjustments adopted, the reliability of these results may be threatened. Another limitation is the low response rate. The reason for the low response rate could be because organizations are afraid of the potential consequences of divulging disaster-related information (Auf der Heide 1989). Furthermore, there is a potential for selection bias. Organizations that are more confident about their adoption of hazard adjustments may be more 
likely to answer the surveys than organizations that are less confident about their adoption of hazard adjustments. Despite these limitations, the author is optimistic that the findings in this study will contribute to the hazard adjustment literature at the organizational level. However, caution is warranted when generalizing the results of this study.

More research is needed on active and passive hazard adjustments at the organizational level. For instance, it may be worthwhile to treat organization size as a continuous variable and examine its impact on the adoption of active and passive hazard adjustments. Future research endeavors may also consider investigating whether active hazard adjustments are more proactive than passive hazard adjustments in helping organizations reduce the impacts of environmental hazards. In addition, researchers might consider studying whether the determinants of active hazard adjustments are different from the determinants of passive hazard adjustments at the organizational level. Although some prior studies suggest that the reason why large organizations adopt more hazard adjustments is because they have more resources, the veracity of this claim should be tested more thoroughly in order to develop more effective policies and incentives for organizational adoption of proactive adjustments.

\section{References}

Alesch, D. J., Holly, J. N., Mittler, E., and Nagy, R. 2001. Organizations at Risk: What Happens When Small Businesses and Not-for-Profits Encounter Natural Disasters. Fairfax, VA: Public Entity Risk Institute.

Arlikatti, S. 2009. Adoption of Earthquake Hazard Adjustments by Households in USA. Saarbrucken: VDM Verlag.

Atwood, L. E. and Major, A. M. 2000. "Optimism, Pessimism, and Communciation Behavior in Response to an Earthquake Prediction." Public Understanding of Science 9: 1-15.

Auf der Heide, E. 1989. Disaster Response: Principles of Preparation and Coordination. Available online at: Orgmail2.coe-dmha.org/dr/flash.htm

Berke, P. R. and Beatley, T. 1992. Planning for Earthquakes: Risks, Politics, and Policy. Baltimore: John Hopkins University Press.

Burby, R. J., May, P. J., Malizia, E. E., and Levine, J. 2000. "Building Code Enforcement Burdens and Central City Decline." Journal of American Planning Association 66(2): 143-161.

Burton, I., Kates, R. W., and White, G. F. 1978. The Environment as Hazard. London: Oxford University Press. 
Celsi, R., Wolfinbarger, M. and Wald, D. 2005. "The Effect of Earthquake Measurement Concepts and Magnitude Anchoring on Individuals' Perceptions of Earthquake Risk." Earthquake Spectra 21(4): 987-1008.

Cutter, S. L., Burton, C. G., and Emrich, C. T. 2010. "Disaster Resilience Indicators for Benchmarking Baseline Conditions." Journal of Homeland Security and Emergency Management 7(1): Article 51.

Dahlhamer, J. M. and D'Souza, M. J. 1997. "Determinants of Business Disaster Preparedness in Two U.S. Metropolitan Areas." International Journal of Mass Emergencies and Disasters 15: 265-281.

Davis, M. S. 1989. "Living Along the Faultline: An Update on Earthquake Awareness and Preparedness in Southern California." Urban Resources 5: 8-14.

Dooley, D., Catalano, R., Mishra, S., and Serxner, S. 1992. "Earthquake Preparedness: Predictors in a Community Survey." Journal of Applied Social Psychology 22: 451-470.

Drabek, T. E. 1991. “Anticipating Organizational Evacuations: Disaster Planning by Managers of Tourist-Oriented Private Firms." International Journal of Mass Emergencies and Disasters 9(2), 219-245.

Drabek, T. E. 1994a. "New Study Shows that Growing Tourist Industry is Inadequately Prepared for Emergencies.” Hazard Technology 14(1): 1721.

Drabek, T. E. 1994b. Disaster Evacuation and the Tourist Industry (No. 57). Boulder, CO: Institute of Behavioral Science, University of Colorado.

Drabek, T. E., Mushkatel, A. H., and Kilijanek, T. S. 1983. Earthquake Mitigation Policy: The Experience of Two States (Monograph No. 37). Boulder: The University of Colorado.

Edwards, M. L. 1993. "Social Location and Self-Protective Behavior: Implications for Earthquake Preparedness." International Journal of Mass Emergencies and Disasters 11: 293-304.

Farley, J. E. 1998. Earthquake Fears, Predictions, and Preparations in MidAmerica: Carbondale, IL: Southern Illinois University Press.

Ge, Y., W.G. Peacock and M.K. Lindell. 2011. "Florida Households' Expected Responses to Hurricane Hazard Mitigation Incentives." Risk Analysis, doi: 10.1111/j.1539-6924.2011.01606.x.

Jackson, E. L. 1977. "Public Response to Earthquake Hazard." California Geology 30: 278-280.

Jackson, E. L. 1981. "Response to Earthquake Hazard: The West Coast of North America." Environment and Behavior 13: 387-416. 
Sadiq: Active and Passive Hazard Adjustments

Jackson, E. L. and Mukerjee, T. "1974. Human Adjustment to the Earthquake Hazard of San Francisco, California." In G. F. White (Ed.), Natural Hazards: Local, National and Global. New York: Oxford University Press, 160-166.

Lindell, M. K. and Perry, R. W. 2000. "Household Adjustments to Earthquake Hazard: A Review of Research." Environment and Behavior 32(4): 461501.

Lindell, M. K. and Prater, C. S. 2002. "Risk Area Residents' Perceptions and Adoption of Seismic Hazard Adjustments." Journal of Applied Social Psychology 32: 2377-2392.

Lindell, M. K. and Whitney, D. J. 2000. "Correlates of Household Seismic Hazard Adjustment Adoption". Risk Analysis 20: 13-25.

Lindell, M. K. and Perry, R. W. (2007). "Planning and Preparedness." In W. L. Waugh and K. J. Tierney (Ed.), Emergency Management: Principles and Practice for Local Governments (Second edition). Washington, D.C.: ICMA Press.

Lindell, M. K., Arlikatti, S., and Prater, C.S. 2009. "Why People Do What They Do to Protect Against Earthquake Risk: Perceptions of Hazard Adjustment Attributes." Risk Analysis 29(8): 1072-1088.

Major, A. M. 1998. "The Utility of Situational Theory of Publics for Assessing Public Response to a Disaster Prediction.” Public Relations Review, 24(4): 489-508.

May, P. J. 1986. Disaster Policy Implementation: Managing Programs under Shared Governance. New York: Plenum Press.

May, P. J. and Birkland, T. A. 1994. "Earthquake Risk Reduction: An Examination of Local Regulatory Efforts." Environmental Management 18: 923-937.

May, P. J. and Wood, R. S. 2003. "At the Regulatory Front Lines: Inspectors' Enforcement Styles and Regulatory Compliance." Journal of Public Administration Research and Theory 13(2): 117-139.

Mileti, D. S. 1999. Disasters by Design: A Reassessment of Natural Hazards in the United States. Washington, D.C.: Joseph Henry Press.

Mileti, D. S., Darlington, J. D., Fitzpatrick, C., and O'Brien, P. W. 1993. Communicating Earthquake Risk: Societal Response to Revised Probabilities in the Bay Area. Fort Collins: Hazard Assessment Laboratory and Dept. of Sociology, Colorado State University.

Mulilis, J. P. and Duval, T. S. 1995. "Negative Threat Appeals and Earthquake Preparedness: A Person-Relative-To-Event Pre Model of Coping with Threat." Journal of Applied Social Psychology 25: 1319-1339.

Mushkatel, A. and Nigg, J. M. 1987. "Opinion Congruence and the Formulation of Seismic Safety Policies.” Policy Studies Review 6: 645-656. 
Nigg, J. M. 1996. The Social Impacts of Physical Processes: How Do We Manage What We Can't Control? (Preliminary Paper). Newark: Disaster Research Center, University of Delaware.

Nigg, J. and Tierney, K. J. 1994. "Projections of Business Disruption Due to Earthquake Effects in Memphis, Tennessee." Paper presented at the Natural Hazard Research Symposium, Louisville, KY.

Olshansky, R. B. 1994. Seismic Hazard Mitigation in the Central United States: The Role of the States. USGS Professional Paper 1538-G. Washington, D.C.: United States Government Printing Office.

Palm, R. and J. Carroll. 1998. Illusions of Safety: Culture and Earthquake Hazard Response in California and Japan. Boulder, CO: Westview Press.

Prater, C. S. and Lindell, M. K. 2000. "Politics of Hazard Mitigation." Natural Hazards Review 1(2): 73-81.

Quarantelli, E. L., Lawrence, C., Tierney, K., and Johnson, T. 1979. Initial Findings from a Study of Socio-Behavioral Preparations and Planning for Acute Chemical Hazard Disasters. Columbus, OH: Disaster Research Center, Department of Sociology, Ohio State University.

Quarantelli, E. L. 2003. A Social Science Research Agenda for the Disasters of the $21^{\text {st }}$ Century: Theoretical, Methodological, and Empirical Issues and Their Professional Implementation. Newark: Disaster Research Center, University of Delaware.

Sadiq, A. A. 2009. Mitigating and Preparing for Disasters: A Survey of Memphis Organizations. Available online at: http://hdl.handle.net/1853/28187.

Sadiq, A. A. 2010. "Digging through Disaster Rubble in Search of the Determinants of Organizational Mitigation and Preparedness." Risk, Hazards \& Crisis in Public Policy 1(2): Article 2.

Sadiq, A. A. and Weible, C. 2010. "Obstacles and Disaster Risk Reduction: Survey of Memphis Organizations." Natural Hazards Review 11(3): 110117.

Schwab, A. K., Eschelbach, K., and Brower, D. J. 2007. Hazard Mitigation and Preparedness. Hoboken, NJ: John Wiley and Sons, Inc.

Stephens, C. 2007. LRA Releases Updated Report on Katrina, Rita Impact on Louisiana Businesses. Accessed at http://www.lra.louisiana.gov/index.cfm?md=newsroom\&tmp=detail\&arti cleID=157 On September 27, 2011.

Tierney, K. J. 1997. Impacts of Recent Disasters on Businesses: The 1993 Midwest Floods and the 1994 Northridge Earthquake (No. NCEER-SP0001). Buffalo: Multidisciplinary Center for Earthquake Engineering and Research, State University of New York at Buffalo. 
Turner, R. H. 1983. "Waiting for Disaster: Changing Reactions to Earthquake Forecasts in Southern California." International Journal of Mass Emergencies and Disasters 1: 307-334.

Turner, R. H., Nigg, J. M., and Paz, D. 1986. Waiting for Disaster: Earthquake Watch in California. Berkeley: University of California Press.

United States Census Bureau. 2010. Interactive Population Map. Accessed at http://2010.census.gov/2010census/popmap/ on July 18, 2011.

United States Geological Survey. 1998. Reducing Earthquake Losses Throughout the United States: The Mississippi Valley- "Whole Lotta Shakin' Goin' On”. Accessed at http://quake.usgs.gov/prepare/factsheets/NewMadrid/ on April 22, 2007.

United States Geological Survey. 2008. Historic Earthquakes: New Madrid Earthquakes. Accessed at http://earthquake.usgs.gov/earthquakes/states/events/1811-1812.php on August 1, 2008.

Webb, G. R., Tierney, K. J., and Dahlhamer, J. M. 2000. "Business and Disasters: Empirical Patterns and Unanswered Questions." Natural Hazards Review 1(2): 83-90.

Wood, R. S. 2004. "Earthquake Entrepreneurs: Local Policy Systems and the Regulation of Public Risks in California." State and Local Government Review 36(3): 198-211. 